\title{
GAMBARAN PENGOLAHAN AIR LIMBAH RUMAH SAKIT JIWA DAERAH PROVINSI LAMPUNG TAHUN 2020
}

\author{
Tri Fitria Ulfa ${ }^{1}$, Imam Santosa ${ }^{2}$, Haris Kadarusman ${ }^{3}$, Ferizal Masra ${ }^{4}$ \\ Politeknik Kesehatan Tanjung Karang \\ E-mail : trifitriaulfa99@gmail.com
}

\begin{abstract}
Abstrack: Overview Of Wastewater Treatment For Mental Hospitals Lampung Province Region In 2020. The hospital is one of the efforts to improve health consisting of medical centers and doctors' offices which are also supported by other units, such as operating rooms, laboratories, pharmacy, administration, kitchen, laundry, waste and waste treatment, as well as organizing education and training. The purpose of this study was to determine the description of wastewater treatment in Lampung Province Mental Hospital in 2020. The type of this research was a descriptive study using qualitative methods, with the object of research being the entire wastewater treatment system of Lampung Province Mental Hospital in 2020. Data collection obtained through observations and observations of the condition of the drainage of wastewater treatment, and interviews with related sections, namely the sanitation department and WWTP officers of Lampung Province Mental Hospital about the wastewater treatment process. From the results of the research that has been done, it can be seen in the treatment of wastewater in the Lampung Provincial Mental Hospital that has not gone well. In the treatment of wastewater treatment plants WWTP off, the wastewater from laundry is not flowed to WWTP, the inspection of wastewater quality is not in accordance with established regulations.
\end{abstract}

Keywords: WWTP (Wastewater Treatment Plant)

\begin{abstract}
Abstrak: Gambaran Pengolahan Air Limbah Rumah Sakit Jiwa Daerah Provinsi Lampung Tahun 2020. Rumah sakit merupakan salah satu upaya peningkatan kesehatan yang terdiri dari balai pengobatan dan tempat praktik dokter yang juga ditunjang oleh unitunit lainnya, seperti ruang operasi, laboratorium, farmasi, administrai, dapur, laundry, pengolahan sampah dan limbah, serta penyelenggaraan pendidikan dan pelatihan. Tujuan penelitian ini adalah untuk mengetahui gambaran pengolahan air limbah Rumah Sakit Jiwa Daerah Provinsi Lampung Tahun 2020. Jenis penelitian ini adalah penelitian deskriptif dengan menggunakan metode kualitatif, dengan objek penelitian yaitu seluruh sistem pengolahan air limbah Rumah Sakit Jiwa Daerah Provinsi Lampung Tahun 2020. Pengumpulan data yang diperoleh yaitu melalui observasi dan pengamatan kondisi pengaliran pengolahan air limbah, dan wawancara dengan bagian yang terkait yaitu bagian sanitasi serta petugas IPAL Rumah Sakit Jiwa Provinsi Lampung tentang proses pengolahan air limbah. Dari hasil penelitian yang sudah dilakukan maka dapat diketahui dalam pengolahan air limbah Rumah Sakit Jiwa Daerah Provinsi Lampung belum berjalan dengan baik. Dalam pengolahan air limbah mesin IPAL dalam keadaan mati, air limbah yang berasal dari laundry tidak dialirkan ke IPAL, pemeriksaan kualitas air limbah tidak sesuai dengan peraturan yang sudah ditetapkan.
\end{abstract}

Kata kunci; IPAL (Instalasi Pengolahan Air Limbah)

\section{PENDAHULUAN}

Rumah sakit merupakan salah satu upaya peningkatan kesehatan yang terdiri dari balai pengobatan dan tempat praktik dokter yang juga ditunjang oleh unit-unit lainnya, seperti ruang operasi, laboratorium, farmasi, administrai, dapur, laundry, pengolahan sampah dan limbah, serta penyelenggaraan pendidikan dan pelatihan. Selain membawa dampak positif bagi masyarakat, rumah sakit juga memiliki kemungkinan membawa dampak negatif. Dampak negatifnya dapat berupa pencemaran dari suatu proses kegiatan, yaitu bila limbah yang 
dihasilkan tidak dikelola dengan baik (Asmadi,2013).

Berdasarkan undang-undang

No.44 Tahun 2009 tentang rumah sakit, yang dimaksud rumah sakit adalah institusi pelayanan kesehatan yang menyelenggarakan pelayanan kesehatan perorangan secara paripurna yang menyediakan rawat inap, rawat jalan, dan gawat darurat. Disamping kegiatan pelayanan kesehatan untuk penyembuh pasien, rumah sakit juga menjadi media pemaparan dan atau penularan penyakit bagi para pasien, petugas, pengunjung maupun masyarakat sekitar yang tinggal dekat rumah sakit yang disebabkan oleh agent (komponen penyebab penyakit yang terdapat di lingkungan rumah sakit).

Dengan semakin meningkatnya jumlah fasilitas pelayanan kesehatan maka mengakibatkan semakin meningkatnya potensi pencemaran lingkungan, karena kegiatan pembuangan limbah khususnya air limbah akan memberikan konstribusi terhadap penurunan tingkat kesehatan manusia. Limbah rumah sakit adalah semua limbah yang dihasilkan dari kegiatan rumah sakit dalam bentuk padat, cair, dan gas. Limbah cair adalah semua air buangan termasuk tinja yang berasal dari kegiatan rumah sakit yang kemungkinan mengandung mikroorganisme patogen, bahan kimia beracun dan radioaktif yang berbahaya bagi kesehatan. Oleh karena itu, potensi dampak air limbah rumah sakit terhadap kesehatan masyarakat sangat besar, maka setiap rumah sakit diharuskan mengolah air limbahnya sampai memenuhi persyaratan standar yang berlaku (Depkes,2004).

Rumah sakit jiwa daerah provinsi lampung merupakan satu-satunya rumah sakit jiwa yang ada didaerah provinsi Lampung yang beralamat di Jalan Raya Kurungan Nyawa, Kec. Gedong Tataan, Kabupaten Pesawaran. Selain merawat dan menyembuhkan pasien gangguan jiwa, seperti rumah sakit biasa pada umum nya Rumah Sakit Jiwa Daerah Provinsi Lampung juga berpotensi menimbulkan dampak negative yang dihasilkan oleh kegiatan pelayanan kesehatan berupa air limbah.

Rumah Sakit Jiwa Provinsi Lampung sudah memiliki Instalasi Pengolahan Air Limbah (IPAL), namun air limbah dari hasil pelayanan kesehatan yang dialirkan hanya dari ruangan radiologi, farmasi, gizi, dan laboratorium. Dalam pengolahan air limbah di Rumah Sakit Jiwa Daerah Provinsi Lampung masih belum terlaksana dengan baik, seperti halnya pada penyaluran air limbah yang berasal dari laundry tidak dialirkan ke dalam IPAL. Menurut Permenkes Nomor 07 Tahun 2019 tentang Kesehatan Lingkungan Rumah Sakit bahwa air limbah dari seluruh sumber dari bangunan/kegiatan rumah sakit harus diolah dalam instalasi pengolahan air limbah, limbah yang berasal dari kegiatan laundry harus dilengkapi saluran air limbah tertutup yang dilengkapi dengan pengolahan awal (pre-treatment). Kemudian selanjutnya dialirkan ke Instalasi Pengolahan Air Limbah. Akan tetapi, air limbah yang berasal dari laundry tidak diolah terlebih dahulu melainkan dibuang langsung ke halaman belakang rumah sakit. Air limbah yang dihasilkan dari kegiatan rumah sakit harus diperhatikan kualitas air limbahnya. Apabila dalam pengolahan air limbah tidak terlaksana dengan baik maka akan mempengaruhi kualitas air limbah tersebut dan akan menimbulkan pencemaran lingkungan. Oleh karena itu air limbah rumah sakit harus diolah dengan baik dan dijalankan secara optimal sehingga menghasilkan kualitas air limbah yang memenuhi baku mutu yang sesuai dengan peraturan yang ada.

\section{BAHAN DAN CARA PENELITIAN}

Jenis penelitian ini adalah penelitian deskriptif dengan menggunakan metode kualitatif, dengan objek penelitian yaitu seluruh sistem pengolahan air limbah Rumah Sakit Jiwa Daerah Provinsi Lampung Tahun 2020. Data yang dikumpulkan pada penelitian ini adalah data primer dan data sekunder. Data primer diperoleh melalui observasi dan 
wawancara. Observasi dilakukan dengan cara pengamatan secara langsung dilengkapi dengan lembar observasi berupa checklist, serta kamera untuk pengambilan gambar pelaksanaan kegiatan pengolahan air limbah yang diterapkan di Rumah Sakit Jiwa Daerah Provinsi Lampung Tahun 2020. Wawancara dilakukan secara langsung kepada responden, yaitu kepada petugas sanitasi.

Data sekunder diperoleh dari data rumah sakit yang bersifat dokumenter dan tercatat di rumah sakit, seperti data mengenai gambaran umum rumah sakit, dan data pemeriksaan kualitas air limbah rumah sakit. Pengolahan dan analisis data diperoleh iperoleh dari hasil pengamatan dan wawancara, kemudian disajikan dalam bentuk tabel dan naratif. Dan analisis data Dilakukan dengan cara membandingkan IPAL yang ada di Rumah Sakit dengan teori yang ada dan hasil pemeriksaan kualitas air limbah dibandingkan KEPMENLH No 58

Dari hasil penelitian yang sudah dilakukan maka diperoleh hasil sebagai berikut: Rumah sakit jiwa daerah provinsi lampung memiliki 2 Instalasi Pengolahan Air Limbah (IPAL), dimana IPAL lama dioperasikan pada tahun 2013 sedangkan IPAL baru belum dioperasikan. Oleh karena itu penelitian ini hanya menjelaskan IPAL yang lama. Sumber air limbah IPAL lama berasal dari ruangan radiologi, farmasi, laboratorium, gizi, UGD, serta ruangan pasien, yang kemudian disalurkan menuju IPAL lama. Tidak semua air limbah disalurkan ke Instalasi Pengolahan Air Limbah. Air limbah yang berasal dari limbah laundry langsung dibuang ke saluran umum menuju badan air.

Dalam proses pengolahan air limbah Rumah Sakit Jiwa Daerah Provinsi Lampung debit air limbah yang dihasilkan yaitu sebesar $1.728 \mathrm{~L} /$ hari pada inlet IPAL. Penggunaan air yang digunakan untuk kegiatan di Instalasi air limbah yang diperoleh dari hasil wawancara dengan petugas adalah volume tangki yang digunakan sebesar $1 \mathrm{~m}^{3}$, sedangkan penggunaan air dalam 1 hari yaitu sebanyak
Tahun 1995 "Baku Mutu Limbah Cair Rumah Sakit."

\section{HASIL PENELITIAN DAN PEMBAHASAN}

Air limbah merupakan gabungan atau campuran dari air dan bahan-bahan pencemar yang terbawa oleh air, baik dalam keadaan terlarut maupun tersuspensi yang terbuang dari sumbersumber pencemar (perkantoran, perumahan, pasar, industri, rumah sakit, dll) dan pada saat tertentu tercampur dengan air tanah, air permukaan atau air hujan. Air tanah, air permukaan atau air hujan pada kondisi tertentu masuk sebagai komponen air limbah, karena pada keadaan sistem saluran pengumpulan air limbah sudah rusak, air alami itu dapat menyatu dengan komponen air limbah dan harus diperhitungkan upaya penangannya. (Soeparman dan suparmin, 2001).

2 tangki, maka dalam 1 hari air limbah yang dihasilkan yaitu $2 \mathrm{~m}^{3}$.

Dalam pengolahan air limbah pada IPAL sumber air limbah berasal dari ruangan radiologi, farmasi, laboratorium, gizi, IGD, serta ruangan pasien, kemudian disalurkan ke Inlet IPAL. Selanjutnya dilakukan pengolahan air limbah yang terdiri dari beberapa tahap, berikut merupakan tahapan pengolahan air limbah Rumah Sakit Jiwa Provinsi Lampung diantaranya yaitu :

\section{Bar Screen}

Proses ini berfungsi sebagai penyaring benda-benda kasar agar mempercepat dan memperlancar proses pengolahan selanjutnya.

Penangkap lemak dan minyak (Skimmer and Grase Trap)

Bak ini berfungsi sebagai pengendap partikel padat yang terkandung dalam air limbah yang berguna untuk mencegah penyumbatan pada pipa atau saluran.

Bak penyetaraan (Equalization Basin)

Bak ini berfungsi sebagai menangani laju aliran dengan mengaduk air limbah agar air limbah tercampur sehingga dapat masuk ke 
Insatalasi Pengolahan Air Limbah secara konstan.

Inlet

Sumber air limbah yang berasal dari ruangan instalasi gizi, laboratorium, dan radiologi dialirkan menuju bak pengolahan pendahuluan terlebih dahulu yang kemudian dialirkan menuju inlet IPAL dan langsung dialirkan ke bak anaerobik pertama.

\section{Anaerobik pertama}

Air limbah yang berasal dari inlet kemudian dialirkan menggunakan sistem gravitasi menuju bak pengendap awal, untuk mengendapkan partikel lumpur pasir dan kotoran lainnya.

\section{Proses equalisasi}

Pada proses ini dipasang 1 buah equalization blower yang berguna untuk mengaduk air limbah agar tidak terjadi pengendapan.

\section{Anaerobik kedua}

Proses ini merupakan proses penguraian dengan menggunakan bakteri anaerob agar dapat menghasilkan unsur-unsur yang lebih sederhana.

\section{Biofiltration chamber}

Pada proses ini dipasang 4 alat aeration blower yang kemudian air diputar kembali menggunakan 1 backwash blower yang selanjutnya dikembalikan ke bak anaerobik pertama untuk diolah kembali.

\section{Desinfectant chamber}

Desinfeksi bertujuan untuk mengurangi atau membunuh mikroorganisme phatogen yang ada dalam limbah cair. Pada proses ini air luapan dari biofiltration chamber kemudian diberi cairan kaporit secara otomatis untuk membunuh mikroorganisme pathogen.

\section{Outlet}

Air yang berasal dari desinfectan chamber kemudian dialirkan menuju outlet yang selanjutnya dibuang ke saluran umum.

Dalam proses pengolahan nya pada IPAL tersebut mengalami kerusakan pada mesin IPAL, kerusakan mesin IPAL ini terjadi pada tahun 2019, akibatnya IPAL tidak beroperasi dengan baik dan dapat mempengaruhi kualitas air limbah. Pemeriksaan kualitas air limbah terakhir dilakukan pada tahun 2018. Hasil pemeriksaan pada tahun 2018 adalah sebagai berikut :

Tabel 1. Hasil analisis air limbah di Rumah Sakit Jiwa Provinsi Lampung Tahun 2018

\begin{tabular}{|c|c|c|c|c|}
\hline $\begin{array}{c}\text { No } \\
\text { Identitas } \\
\text { Sampel } \\
\end{array}$ & Parameter & $\begin{array}{l}\text { Kadar Maksimum } \\
\text { yang diperbolehkan }\end{array}$ & $\begin{array}{c}\text { Hasil } \\
\text { Pengujian }\end{array}$ & Satuan \\
\hline In Let & $\begin{array}{c}\text { MPN-Kuman } \\
\text { Golongan Coli/100 } \\
\mathrm{ml}\end{array}$ & 10.000 & 9.200 & $\begin{array}{c}\text { Jumlah/100 } \\
\text { ml sampel }\end{array}$ \\
\hline Out Let & $\begin{array}{c}\text { MPN-Kuman } \\
\text { Golongan Coli/100 } \\
\mathrm{ml}\end{array}$ & 10. 000 & 1.800 & $\begin{array}{l}\text { Jumlah/100 } \\
\text { ml sampel }\end{array}$ \\
\hline
\end{tabular}




\section{Sumber-Sumber Air Limbah dan Debit Air Limbah Rumah Sakit Jiwa Daerah Provinsi Lampung}

Sumber-sumber air limbah yang dialirkan ke Instalasi Pengolahan Air Limbah hanya berasal dari ruangan radiologi, farmasi, laboratorium, gizi, IGD, serta ruangan pasien. Sedangkan air limbah yang berasal dari ruangan laundry tidak dialirkan ke Instalasi Pengolahan Air Limbah melainkan langsung dibuang ke saluran umum atau dibuang ke lingkungan tanpa dilakukan pengolahan terlebih dahulu. Laundry rumah sakit adalah tempat pencucian linen yang dilengkapi dengan sarana penunjangnya berupa mesin cuci, alat dan desinfektan, mesin uap, pengering dan mesin setrika. Limbah cair laundry kemungkinan besar mengandung mikroorganisme pathogen atau bahan kimia beracun berbahaya yang berpotensi merusak lingkungan. Limbah cair laundry juga dapat mengandung bahan organik dan anorganik. Limbah cair laundry yang tidak dilakukan pengolahan terlebih dahulu dapat mengakibatkan mutu lingkungan menjadi turun kualitasnya, dengan akibat lanjutannya adalah menurunnya derajat kesehatan masyarakat dilingkungan sekitar. Limbah cair yang berasal dari laundry pada umumnya bersifat basa dengan kandungan zat padat total berkisar antara 800-1.200 $\mathrm{mg} / \mathrm{l}$ dan kandungan BOD berkisar antara 400-450 mg/l. Semakin besar angka BOD maka menunjukkan bahwa derajat pengotoran air limbah adalah semakin besar. Hal tersebut dapat mencemari lingkungan sekitar yang dapat menyebabkan penyerapan air ke dalam tanah sehingga dapat mengganggu kehidupan biotik yang dapat menyebabkan kepunahan dan penurunan keanekaragaman jenis. Menurut Permenkes No 7 Tahun 2019 laundry harus dilengkapi saluran air limbah tertutup yang dilengkapi dengan pengolahan awal (pre treatment) sebelum dialirkan ke unit pengolahan air limbah. Sedangkan laundry Rumah Sakit Jiwa Daerah Provinsi Lampung tidak terdapat pengolahan air limbah sebelum dibuang ke saluran umum atau lingkungan. Hal tersebut tidak sesuai dengan peraturan yang sudah ditetapkan. Air limbah pada rumah sakit harus memiliki saluran air limbah tertutup yang dilengkapi dengan pengolahan sebelum dialirkan ke saluran air limbah.

Dalam penyaluran air limbah saluran air limbah harus keadaan tertutup dan saluran berjalan dengan lancar. Akan tetapi, saluran air limbah Rumah Sakit Jiwa Daerah Provinsi Lampung terdapat kendala pada penyaluran sumber air limbah yang berasal dari ruangan gizi. Penyaluran air limbah yang berasal dari ruangan gizi sering mengalami sumbatan pada saluran air limbah, akibatnya penyaluran tidak berjalan dengan baik. Dalam proses pengolahan air limbah Rumah Sakit Jiwa Daerah Provinsi Lampung debit air limbah yang dihasilkan yaitu sebesar $1.728 \mathrm{~L} /$ hari pada inlet IPAL. Rumah Sakit Jiwa Daerah Provinsi Lampung memiliki 105 tempat tidur, untuk hasil air limbah berdasarkan jumlah tempat tidur, dengan 1 tempat tidur menghasilkan air limbah 400 L/hari. Dengan total keseluruhan debit air limbah pada Instalasi Pengolahan Air Limbah yaitu kurang lebih sebesar $20 \mathrm{~m}^{3}$. Dalam pengolahan air limbah sebaiknya air limbah yang berasal dari laundry disalurkan pada Instalasi Pengolahan Air Limbah, dan dilakukan pengolahan pendahuluan terlebih dahulu sebelum dialirkan menuju tahap pengolahan selanjutnya. Limbah yang berasal dari laundry dilakukan pengolahan pendahuluan dikarenakan air limbah banyak mengandung zat kimia berbahaya. Dan dalam penyaluran air limbah, saluran air limbah harus dalam keadaan tertutup agar tidak mencemari lingkungan sekitar, dan saluran berjalan dengan lancar agar tidak menghambat proses pengolahan air limbah. Sebaiknya, saluran yang tersumbat pada saluran air limbah yang berasal dari ruangan gizi Rumah Sakit Jiwa Provinsi Lampung diperbaiki pada bak penyaringan agar dapat memperlancar pada proses pengolahan selanjutnya.

\section{Pengolahan Pendahuluan}

Sebelum mengalami proses pengolahan perlu kiranya dilakukan pembersihanpembersihan agar mempercepat dan memperlancar proses pengolahan selanjutnya. Adapun kegiatan tersebut 
berupa pengambilan benda yang mengendap seperti pasir. Pengolahan pendahuluan digunakan untuk memisahkan padatan kasar, mengurangi ukuran padatan, memisahkan minyak atau lemak, dan proses menyetarakan fluktuasi aliran limbah pada bak penampung. Sumber air limbah yang berasal dari ruangan laboratorium, laundry, instalasi gizi, dan radiologi harus dilakukan pengolahan pendahuluan terlebih dahulu, hal itu dikarenakan air limbah banyak mengandung zat kimia yang berbahaya. Akan tetapi, air limbah yang berasal dari ruangan laundry tidak terdapat pengolahan pendahuluan dan tidak dilakukan pengolahan air limbah. Air limbah yang berasal dari ruangan laboratorium, instalasi gizi dan ruangan radiologi disalurkan pada masing-masing bak pengolahan pendahuluan dan selanjutnya dialirkan menuju kolam penampungan kemudian dialirkan menuju inlet IPAL dan dilakukan pengolahan selanjutnya. Unit yang terdapat dalam pengolahan pendahuluan yaitu saringan (Bar Screen), bak penangkap pasir (Grit Chamber), penangkap lemak dan minyak (Skimmer and Grase Trap), dan bak penyetaraan (Equalization Basin).

Penangkap lemak dan minyak (Skimmer and Grase Trap)

Lemak dan minyak yang terkandung dalam air limbah dapat menyumbat media penyaring. Hal itu dapat mempengaruhi proses pengolahan, dan di Rumah Sakit Jiwa Daerah Provinsi Lampung memiliki penangkap lemak dan minyak.

\section{Bak penyetaraan (Equalization Basin)}

Bak penyetaraan berfungsi sebagai menangani laju aliran dengan mengaduk air limbah agar air limbah tercampur sehingga dapat masuk ke Insatalasi Pengolahan Air Limbah secara konstan. Pada pengolahan air limbah Rumah Sakit Jiwa Daerah Provinsi Lampung terdapat pengolahan penyetaraan.

\section{Pengolahan Tahap Pertama (Primary Treatment)}

Pengolahan pertama merupakan pengolahan secara fisik. Pengolahan ini berfungsi mengumpulkan air limbah dari saluran sebelum menuju bak pengendap pertama. Partikel-partikel padatan yang berukuran besar akan disisihkan pada tahap ini, baik berupa penyaringan ataupun pengendapan. Selain itu pengolahan ini merupakan pengolahan sebelum limbah cair masuk ketahap pengelolaan kedua.

\section{Pengolahan Tahap Kedua (Secondary Treatment)}

Pengolahan kedua umumnya mencakup proses biologis untuk mengurangi bahanbahan organik melalui mikroorganisme yang ada didalamnya. Penambahan oksigen adalah suatu usaha pengambilan zat pencemar yang terkandung didalam air limbah. Pada prosesnya terdapat 2 cara untuk menambahkan oksigen kedalam air limbah yaitu dengan memasukkan udara kedalam air limbah atau menggunakan baling-baling. Pada proses pengolahan kedua Instalasi Pengolahan Air Limbah Rumah Sakit Jiwa Daerah Provinsi Lampung menggunakan aerasi dengan 4 baling-baling (Aeration Blower). Selanjutnya setelah proses pengolahan kedua dilakukan proses desinfeksi sebelum dibuang kesaluran umum.

\section{Pengolahan Tahap Ketiga (Tertiary Treatment)}

Pengolahan ini merupakan kelanjutan dari pengolahan-pengolahan terdahulu. Oleh karena itu, pengolahan ini akan digunakan apabila pada pengolahan pertama dan kedua masih banyak terdapat zat tertentu yang masih berbahaya bagi masyarakat. Pada Rumah Sakit Jiwa Daerah Provinsi Lampung tidak ada pengolahan tahap ketiga.

\section{Kualitas Air Limbah}

Dari hasil penelitian yang sudah dilakukan pemeriksaan kualitas air limbah terakhir dilakukan pada tahun 2018, hal itu dikarenakan pada awal tahun 2019 mesin blower pada Instalasi Pengolahan Air Limbah yang lama mengalami kerusakan yaitu mesin dalam keadaan mati. Dalam pengolahan air limbah terdapat beberapa bak untuk mengolah air limbah, selain itu dalam mengolah air limbah juga dibantu dengan mesin blower pada kolam aerasi sehingga terjadi penambahan oksigen untuk membantu bakteri dalam proses dekomposisi. Mesin blower dalam pengolahan air limbah berperan sangat besar dalam proses pengolahan, apabila 
mesin blower tidak berfungsi dengan baik maka dapat mempengaruhi kualitas air limbah. Kualitas air limbah yang buruk dapat mencemari lingkungan.

Pemeriksaan kualitas air limbah pada tahun 2018 hanya melakukan pemeriksaan parameter MPN-coli dengan hasil pemeriksaan pada inlet sebesar 9. 200 dan outlet sebesar 1. 800. Hasi pemeriksaan masih dibawah baku mutu KEPMENLH No 58 Tahun 1995 tentang tentang baku mutu limbah cair bagi kegiatan rumah sakit. Dan pada tahun 2019 belum dilakukan pemeriksaan kualitas air limbah sampai saat ini. Bakteri coliform merupakan golongan mikroorganisme yang lazim digun akan sebagai indikator, dimana bakteri ini dapat menjadi sinyal untuk menentukan suatu sumber air telah terkontaminasi oleh patogen atau tidak. Pada bakteri Coliform ini menghasilkan zat etionin yang dapat menyebabkan kanker. Metode MPN sering dipakai untuk menghitung jumlah populasi bakteri E.coli dalam air limbah, karena kemampuannya dalam melakukan fermentasi dalam substrat media cair lactose Broth. Metabolitnya berupa gas karbon dioksida yang akan terperangkap dalam tabung Durham yang sengaja dimasukan dalam tabung reaksinya dengan posisi terbalik. Nilai MPN adalah perkiraan jumlah unit tumbuh (growth unit) atau unit pembentuk-koloni (colony-forming unit) dalam sampel. Namun, pada umumnya, nilai MPN juga diartikan sebagai perkiraan jumlah individu bakteri. Satuan yang digunakan, umumnya per $100 \mathrm{~mL}$ atau per gram. Jadi misalnya terdapat nilai MPN 10/g dalam sebuah sampel air, artinya dalam sampel air tersebut diperkirakan setidaknya mengandung 10 coliform pada setiap gramnya. Makin kecil nilai MPN, maka air tersebut makin tinggi kualitasnya, dan makin layak minum. Dalam pemeriksaan kualitas air limbah sebaiknya pemeriksaan tidak hanya melakukan pemeriksaan MPN-coli saja, menurut KEPMENLH No 58 Tahun 1995 tentang baku mutu limbah cair bagi kegiatan rumah sakit terdiri dari beberapa baku mutu seperti parameter suhu, $\mathrm{pH}, \mathrm{BOD}, \mathrm{COD}, \mathrm{TSS}$, $\mathrm{NH}_{3}, \mathrm{PO}_{4}$, dan lain sebagainya juga perlu dilakukan pemeriksaan kualitas air limbah.
Nilai pH air digunakan untuk mengekspresikan kondisi keasaman (konsentrasi ion hidrogen air limbah. Skala pH berkisar 1-14, kisaran nilai pH 1-7 termasuk kondisi asam, $\mathrm{pH}$ 7-14 termasuk kondisi basa dan pH 7 adalah kondisi netral. Padatan-padatan, yaitu TS (total solid), SS (suspended solid), dan DS (disselved solid), serta kondisinya sebagai fraksi volatil dan fixed dapat digunakan untuk menentukan kepekatan air limbah, efisiensi proses, dan beban unit proses. BOD (biochemical oxygen dimand) adalah oksigen yang diperlukan mikroorganisme untuk mengoksidasi senyawa-senyawa kimia. COD adalah kebutuhan oksigen dalam proses oksidasi secara kimia. Nilai COD akan selalu lebih besar daripada BOD karena senyawa lebih mudah teroksidasi secara kimia daripada secara biologi. Nitrogen terdapat limbah organik dalam berbagai bentuk yang meliputi empat spesifikasi, yaitu nitrogen organik, nitrogen amonia (ion amonia dan ion bebas, nitrogen nitrit, dan nitrogen nitrat). Dalam air limbah yang dingin dan segar, biasanya kandungan nitrogen organik relatif lebih tinggi daripada nitrogen amonia. Sebaliknya dalam air limbah yang hangat kandungan nitrogen organik relatif lebih rendah daripada nitrogen amonia. Nitri dan nitrat terdapat dalam air limbah dalam konsentrasi yang sangat rendah. Fosfor merupakan elemen penting dalam proses metabolisme organisme-organisme biologis.

Rumah Sakit Jiwa Provinsi Lampung hanya melakukan pemeriksaan baku mutu MPN-coli saja, hal itu tidak sesuai dengan peraturan yang sudah ditetapkan. Apabila kualitas air limbah tidak dilakukan pemeriksaan secara keseluruhan dan air limbah tidak dilakukan pengolahan terlebih dahulu maka akan berdampak pada lingkungan, kesehatan dan kerusakan benda. Air limbah dapat mengandung bibit penyakit yang dapat menimbulkan penyakit bawaan air (waterborne disease). Selain itu, didalam air limbah mungkin juga terdapat zat-zat berbahaya dan beracun yang dapat menimbulkan gangguan kesehatan bagi makhuk hidup yang mengonsumsinya. Adakalanya, air limbah yang tidak dikelola dengan baik juga dapat menjadi sarang 
vektor penyakit (misalnya, nyamuk, lalat, kecoa, dan lain-lain). Vektor penyakit tersebut dapat membawa mikroorganisme phatogen penyebab penyakit. Dampak air limbah terhadap kesehatan, diantaranya karena air limbah dapat berperan sebagai media penularan penyakit, seperti penyakit kolera, radang usus, hepatitis, serta schistomiasis. Selain sebagai media, dalam air limbah sendiri banyak terdapat bakteri phatogen penyebab penyakit, mengandung bahan-bahan beracun, penyebab iritasi, bau juga bahan-bahan lainnya yang mudah terbakar. Air limbah yang langsung dibuang ke air permukaan (misalnya sungai dan danau) tanpa dilakukan pengolahan dapat mengakibatkan pencemaran permukaan air ini. Sebagai contoh, bahan organik yang terdapat dalam air limbah bila dibuang langsung kesungai dapat menyebabkan penurunan kadar oksigen yang terlarut didalam sungai tersebut. Dengan demikian akan menyebabkan kehidupan didalam air yang membutuhkan oksigen akan terganggu, dalam hal ini akan mengurangi perkembangannya. Kandungan karbondioksida agresif pada air limbah akan mempercepat proses terjadinya karat pada benda yang terbuat dari besi. Kondisi ini dapat menyebabkan pada meningkatnya biaya pemeliharaan dan menimbulkan biaya material.Selain itu air limbah dengan karakteristik $\mathrm{pH}$ rendah atau tinggi juga dapat mengakibatkan timbulnya kerusakan pada benda-benda yang dilaluinya.

Dalam pemeriksaan kualitas air limbah juga sebaiknya dilakukan pemeriksaan sekurang-kurangnya satu kali dalam sebulan sesuai peraturan yang ada. Sedangkan, Rumah Sakit Jiwa Provinsi Lampung melakukan pemeriksaan kualitas air limbah terakhir pada tahun 2018 dan IPAL tidak beroperasi dengan baik. Menurut peraturan yang ada limbah cair sebelum dibuang ke lingkungan terlebih dahulu melakukan pengelolaan sehingga baku mutu limbah cair yang dibuang ke lingkungan tidak melampaui baku mutu limbah cair yang telah ditetapkan. Pada proses pengolahan air limbah di Rumah Sakit Jiwa Provinsi Lampung tahun 2020 tidak dilakukan sesuai dengan prosedur pemakaian IPAL. Seharus nya mesin IPAL beroperasi dengan baik untuk keperluan oksigen yang dibutuhkan oleh bakteri, namun pada kenyataannya mesin IPAL dalam keadaan mati sejak tahun 2018. Hal ini menyebabkan pengolahan air limbah tidak bekerja secara optimal. Sebaiknya, kepala sanitasi untuk membuat pengusulan tentang penyaluran air limbah yang berasal dari laundry agar disalurkan ke Instalasi Pengolahan Air Limbah sebelum dialirkan ke saluran umum. Melakukan perbaikan saluran air limbah yaitu dengan menyalurkan air limbah yang berasal dari laundry menuju IPAL dapat membantu menurunkan kualitas air limbah dan mengoperasikan IPAL sesuai dengan fungsinya agar memenuhi persyaratan menurut KEPMENLH No 58 Tahun 1995 tentang tentang baku mutu limbah cair bagi kegiatan rumah sakit.

\section{KESIMPULAN DAN SARAN}

Proses pengolahan limbah cair di Rumah Sakit Jiwa Daerah Provinsi Lampung belum sesuai dengan prosedur pemakaian IPAL. Pemeriksaan kualitas air limbah pada tahun 218 pada baku mutu MPN-Coli sudah memenuhi baku mutu yang sesuai dengan peraturan menteri lingkungan hidup no 58 tahun 1995.

Bagi kepala sanitasi sebaiknya membuat usulan perbaikan prosedur pemakaian IPAL serta pemeriksaan kualitas air limbah dilakukan sebulan sekali untuk swapantau dan minimal 3 bulan sekali uji petik agar dapat mengontrol kualitas air limbah yang dihasilkan oleh Instalasi Pengolahan Air Limbah Rumah Sakit Jiwa Daerah Provinsi Lampung.

\section{KEPUSTAKAAN}

1. Peraturan Menteri Lingkungan Hidup Republik Indonesia Nomor 58/MENLH/1995. Tentang Baku Mutu Air Limbah. Jakarta: Sekertariat

2. Asmadi.2013.Pengolahan Limbah Medis Rumah Sakit.Yogyakarta:Goysen Publishing.136 halaman

3. Peraturan Menteri Kesehatan Republik Indonesia Nomor 07 Tahun 2019. Tentang Kesehatan Lingkungan Rumah Sakit. Jakarta: KEPMENKES 
Tri Fitria Ulfa ${ }^{1}$, Imam Santosa ${ }^{2}$, Haris Kadarusman ${ }^{3}$, Ferizal Masra ${ }^{4}$, Gambaran

4. Soeparman,suparmin.2001.Pembua n gan Tinja dan Limbah Cair, Buku Kedokteran.170 halaman

5. Undang-Undang Republik Indonesia No. 44 tahun 2009.Tentang Rumah Sakit.Jakarta 
